International Journal of Computing and Business Research (IJCBR)

ISSN (Online) : 2229-6166

International Manuscript ID : 22296166V7|1201701

Volume 7 Issue 1 May - June 2017

\title{
Non Performing Assets: A Study of Public Bank and Private Bank
}

\author{
Munish Gupta \\ Assistant Professor, Faculty of Commerce, Arya (PG) College, Panipat, Haryana, India \\ Payal \\ Faculty of Commerce, Haryana, India \\ Priya Gupta \\ Assistant Professor, Arya (PG) College, Panipat, Haryana, India
}

\begin{abstract}
The NPA is one of the biggest problems that the Banks are facing today. If the proper management of the NPAs is not undertaken it would hamper the business of the banks. If the concept of NPAs is taken very lightly it would be dangerous for the whole banking sector. The NPAs would destroy the current profit, interest income and would affect the smooth functioning of the recycling of the funds. Banks also redistribute losses to other borrowers by charging higher interest rates, lower deposit rates and higher lending rates repress savings and financial markets, which hampers economic growth. Public sector banks are more efficient than private sector banks with regard to the management of non-performing assets.

In India, Non-performing assets are one of the major concerns for banks. NPA is the best indicator for the health of the banking industry. NPAs reflect the performances of banks NPAs is the primary indicators of credit risk. NPAs are an inevitable burden on the banking industry. Hence the success of a bank depends upon methods of managing NPAs.
\end{abstract}

The Public Sector Banks have shown very good performance over the private sector banks as far as the financial operations are concerned. The Public Sector Banks have also shown comparatively good result. However, the only problem of the Public Sector Banks these days are the increasing level of the non performing assets. The non performing assets of the Public Sector Banks have been increasing regularly year by year. On the contrary, the non performing assets of private sector banks have been decreasing regularly year by year except some years. Generally reduction in NPAs shows that banks have strengthened their credit appraisal processes over the years and increased in NPAs shows the necessity of provisions, which bring down the overall profitability of banks. The Indian banking sector is facing a serious problem of NPA. The magnitude of NPA is comparatively higher in public sectors banks than private sector banks. To improve the efficiency and profitability of banks the NPA need to be reduced and controlled.

Keywords: Gross NPA, Net NPA, Private Banks, Public Banks 


\section{International Journal of Computing and Business Research (IJCBR)}

ISSN (Online) : 2229-6166

International Manuscript ID : 22296166V7I1201701

Volume 7 Issue 1 May - June 2017

\section{Introduction}

Granting of credit for economic activities is the prime duty of banking. Apart from raising resources through fresh deposits, borrowings and recycling of funds received back from borrowers constitute a major part of funding credit dispensation activity. Lending is generally encouraged because it has the effect of funds being transferred from the system to productive purposes, which results into economic growth. However lending also carries a risk called credit risk, which arises from the failure of borrower. Non-recovery of loans along with interest forms a major hurdle in the process of credit cycle. Thus, these loan losses affect the bank's profitability on a large scale. Though complete elimination of such losses is not possible, but banks can always aim to keep the losses at a low level.

Non-performing Asset (NPA) has emerged since over a decade as an alarming threat to the banking industry in our country sending distressing signals on the sustainability and endurability of the affected banks. The positive results of the chain of measures affected under banking reforms by the Government of India and RBI in terms of the two Narasimhan Committee Reports in this contemporary period have been neutralized by the ill effects of this surging threat. Despite various correctional steps administered to solve and end this problem, concrete results are eluding. It is a sweeping and all pervasive virus confronted universally on banking and financial institutions. The severity of the problem is however acutely suffered by Nationalized Banks, followed by the SBI group, and the all India Financial Institutions.

\section{Objectives of the Study}

- To study about the Gross NPAs and Net NPAs.

- To study the impact of Gross NPAs and Net NPAs on Public Banks and Private Banks.

- To know the retrieval procedure of NPAs through various channels
- To take corrective measures to avoid future NPAs and to manage existing NPAs in banks.

\section{Classification of Assets:}

Assets are classified into following four categories:

1) Standard Assets

2) Sub-standard Assets

3) Doubtful Assets

4) Loss Assets

1) Standard Assets: Standard assets are the ones in which the bank is receiving interest as well as the principal amount of the loan regularly from the customer. Here it is also very important that in this case the arrears of interest and the principal amount of loan do not exceed 90 days at the end of financial year. If asset fails to be in category of standard asset that is amount due more than 90 days then it is NPA and NPAs are further need to classify in sub categories using norms.

2) Sub-Standard Assets: With effect from 31 March 2005, a sub-standard asset would be one, which has remained NPA for a period less than or equal to 12 month. The following features are exhibited by substandard assets: the current net worth of the borrowers / guarantor or the current market value of the security charged is not enough to ensure recovery of the dues to the banks in full; and the asset has well-defined credit weaknesses that jeopardize the liquidation of the debt and are characterized by the distinct possibility that the banks will sustain some loss, if deficiencies are not corrected.

3) Doubtful Assets: A loan classified as doubtful has all the weaknesses inherent in assets that were classified as sub-standard, with the added characteristic that the weaknesses make collection or liquidation in full, on the basis of currently known facts, conditions and values - highly questionable and improbable. An asset would be classified as 


\section{International Journal of Computing and Business Research (IJCBR)}

ISSN (Online) : 2229-6166

International Manuscript ID : 22296166V7I1201701

Volume 7 Issue 1 May - June 2017

doubtful if it remained in the sub-standard category for 12 months (w.e.f. March 31, 2005)

4) Loss Assets: A loss asset is one which considered uncollectible and of such little value that its continuance as a bankable asset is not warranted, although there may be some salvage or recovery value. Also, these assets would have been identified as, loss assets by the bank or internal or external auditors or the RBI inspection but the amount would not have been written-off wholly.

\begin{tabular}{|l|l|l|}
\hline $\begin{array}{l}\text { Classification } \\
\text { of Assets }\end{array}$ & \multicolumn{1}{|c|}{ Definition } & \multicolumn{1}{c|}{$\begin{array}{c}\text { Rate of } \\
\text { provision }\end{array}$} \\
\hline $\begin{array}{l}\text { Standard } \\
\text { Assets }\end{array}$ & $\begin{array}{l}\text { It does not } \\
\text { create any } \\
\text { problem while } \\
\text { paying interest/ } \\
\text { installments of } \\
\text { the principal. It } \\
\text { usually carries } \\
\text { normal risk } \\
\text { attached to the } \\
\text { business }\end{array}$ & $\begin{array}{l}\text { Provision } \\
\text { required to } \\
\text { be made } \\
\text { against } \\
\text { them }\end{array}$ \\
\hline $\begin{array}{l}\text { Sub-standard } \\
\text { Assets }\end{array}$ & $\begin{array}{l}\text { NPA for a } \\
\text { period } \\
\text { exceeding 12 } \\
\text { months. }\end{array}$ & $\begin{array}{l}\text { Provision } \\
\text { @equired to } \\
\text { be made } \\
\text { against } \\
\text { them }\end{array}$ \\
\hline $\begin{array}{l}\text { Doubtful } \\
\text { Assets }\end{array}$ & $\begin{array}{l}\text { For the } \\
\text { unsecured } \\
\text { portion of } \\
\text { advance } \\
\text { For the secured } \\
\text { portion of } \\
\text { advance } \\
\text { (a) If they } \\
\text { are } \\
\text { consider } \\
\text { doubtful } \\
\text { upto one } \\
\text { year } \\
\text { (b) If they } \\
\text { are } \\
\text { consider }\end{array}$ & @ $100 \%$ \\
@ $20 \%$ \\
@ $30 \%$
\end{tabular}

\begin{tabular}{|l|l|l|}
\hline & $\begin{array}{l}\text { doubtful } \\
\text { upto one } \\
\text { year to } \\
\text { three years } \\
\text { (c) If they } \\
\text { are } \\
\text { consider } \\
\text { doubtful } \\
\text { for more } \\
\text { than three }\end{array}$ & \\
years & \\
\hline Loss Assets & $\begin{array}{l}\text { An asset where } \\
\text { loss has been }\end{array}$ & \\
& identified by $100 \%$ & \\
& the bank or & \\
& internal or & \\
external & \\
auditors or by & \\
& the RBI & \\
inspection. & \\
\hline
\end{tabular}

Types of NPA:

- Gross NPA

- Net NPA

a) Gross NPA: are the sum total of all loan assets that are classified as NPAs as per RBI guidelines as on Balance Sheet date. Gross NPA reflects the quality of the loans made by banks. It consists of all the non standard assets like as sub-standard, doubtful, and loss assets. It can be calculated with the help of following ratio:

$$
\text { Gross NPAs Ratio }=\frac{\text { Gross NPAs }}{\text { Gross Advances }}
$$

b) Net NPA: are those type of NPAs in which the bank has deducted the provision regarding NPAs. Net NPA shows the actual burden of banks. In India, bank's balance sheets contain a huge amount of NPAs and the process of recovery and write off of loans is very time consuming, the provisions the banks have to make against the NPAs according to the central bank guidelines, are quite significant. That is why the difference between gross and net NPA is quite high. It can be calculated by following: 
International Journal of Computing and Business Research (IJCBR)

ISSN (Online) : 2229-6166

International Manuscript ID : 22296166V7I1201701

Volume 7 Issue 1 May - June 2017

Net NPAs $=\frac{\text { Gross NPAs }- \text { Provisions }}{\text { Gross Advances }- \text { Provisions }}$

Analysis of Gross Non Performing Assets of Public and Private Sector Bank

\begin{tabular}{|l|l|l|l|l|l|}
\hline Year & Public Banks & $\begin{array}{l}\text { Private } \\
\text { Banks }\end{array}$ & Year & Public Banks & Private Banks \\
\hline $2001-02$ & 11.09 & 9.64 & $2008-09$ & 2.00 & 2.36 \\
\hline $2002-03$ & 9.36 & 8.08 & $2009-10$ & 2.20 & 2.32 \\
\hline $2003-04$ & 7.80 & 5.85 & $2010-11$ & 2.40 & 1.97 \\
\hline $2004-05$ & 5.50 & 6.00 & $2011-12$ & 2.94 & 1.70 \\
\hline $2005-06$ & 3.60 & 4.40 & $2012-13$ & 3.42 & 1.84 \\
\hline $2006-07$ & 2.70 & 3.10 & $2013-14$ & 4.03 & 2.02 \\
\hline $2007-08$ & 2.20 & 2.30 & $2014-15$ & 4.72 & 2.14 \\
\hline
\end{tabular}

\section{Comparison chart of Gross NPA's of Public Banks and Private Banks}

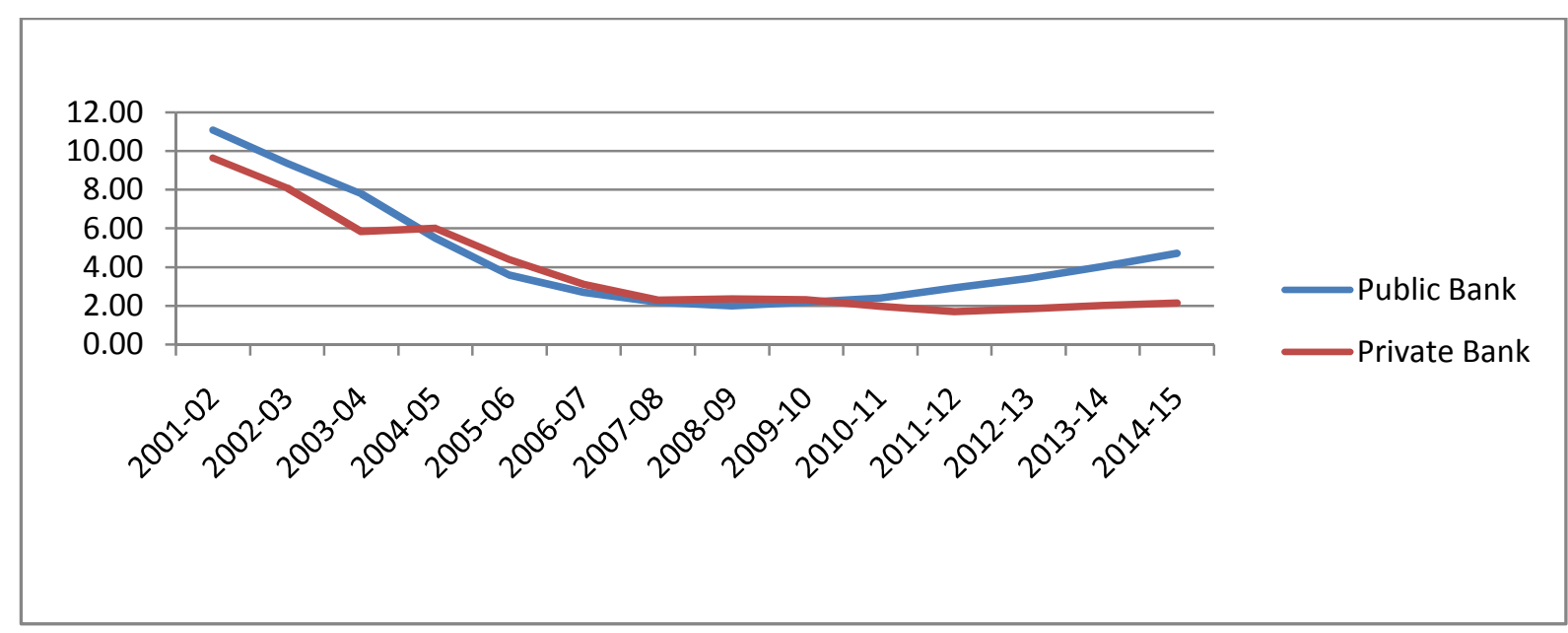

The above figure portrays the trend of Gross NPAs of Public and Private sector Banks in percentage for the period of 15 years i.e. from 2001-02 till 2014-15. The $\mathrm{x}$-axis represents the years whereas $\mathrm{y}$ axis represents the percentage of Gross NPA. We can observe here that the Gross percentage of NPA of Public Banks has been showing downward trend from 2001-02 to 2007-08 and constant till 2009-10 and an upward trend beginning from 2010-11 to 2014-15, and the Gross percentage of NPA of Private Banks has been showing downward trend from 2001-02 to 2007-08 and constant till 2014-15. 
International Journal of Computing and Business Research (IJCBR)

ISSN (Online) : 2229-6166

International Manuscript ID : 22296166V7I1201701

Volume 7 Issue 1 May - June 2017

Analysis of Net Non Performing Assets of Public and Private Sector Banks

\begin{tabular}{|c|c|c|c|c|c|}
\hline Year & Public Banks (\%) & Private Banks (\%) & Year & Public Banks (\%) & Private Banks (\%) \\
\hline $2001-02$ & 5.82 & 5.73 & $2008-09$ & 0.94 & 0.90 \\
\hline $2002-03$ & 4.54 & 4.95 & $2009-10$ & 1.09 & 0.82 \\
\hline $2003-04$ & 3.00 & 2.80 & $2010-11$ & 1.20 & 0.53 \\
\hline $2004-05$ & 2.00 & 2.70 & $2011-12$ & 1.50 & 0.55 \\
\hline $2005-06$ & 1.30 & 1.70 & $2012-13$ & 1.71 & 0.58 \\
\hline $2006-07$ & 1.10 & 1.00 & $2013-14$ & 2.01 & 0.62 \\
\hline $2007-08$ & 1.00 & 0.70 & $2014-15$ & 2.36 & 0.71 \\
\hline
\end{tabular}

\section{Comparison chart of Net NPA's of Public Banks and Private Banks}

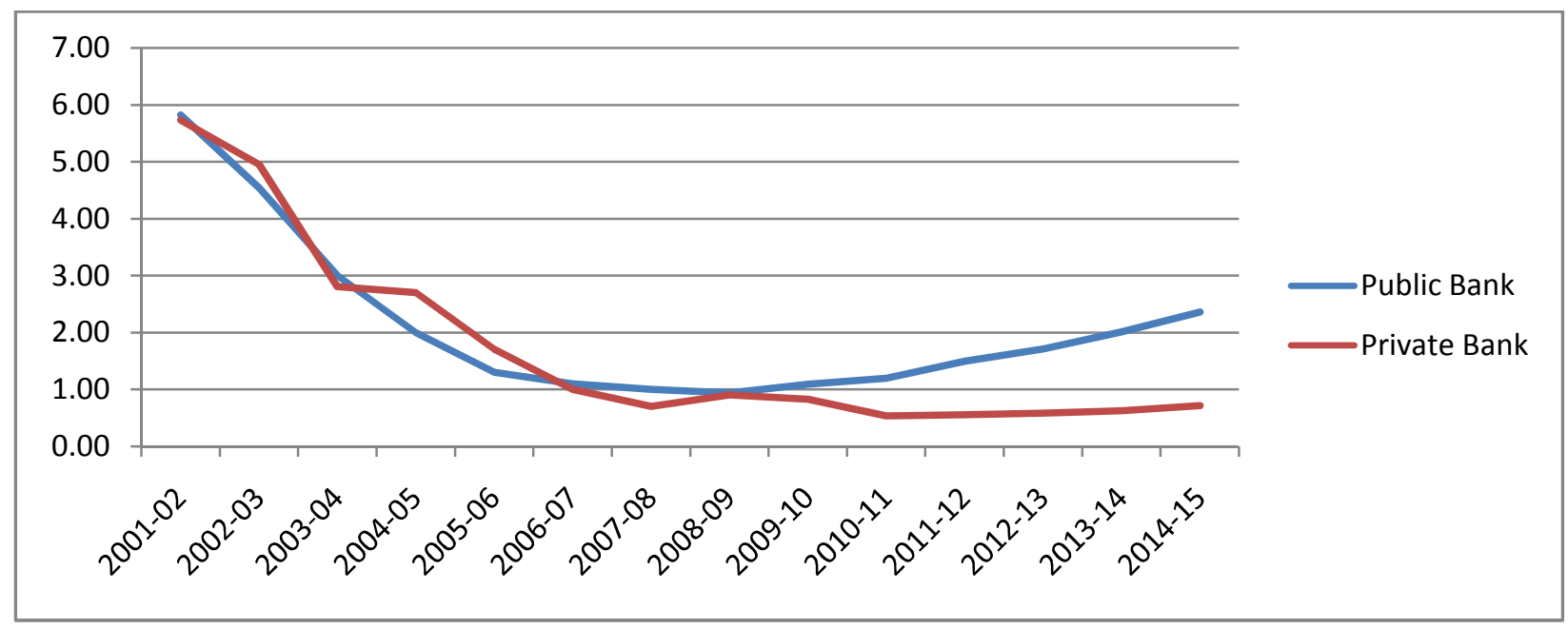

The above figure portrays the trend of Net NPA of Public and Private sector Banks in percentages for the period of 15 years i.e. from 2001-02 till 2014-15. The $\mathrm{x}$-axis represents the years whereas $\mathrm{y}$ axis represents the percentage of Net NPA. We can observe here that the Net percentage of NPA of Public Banks has been showing downward trend from 2001-02 to 2006-07 and constant till 2008-09 and an upward trend beginning from 2009-10 to
2014-15, and the Net percentage of NPA of Private Banks has been showing downward trend from 2001-02 to 2007-08 and constant till 2014-15.

Reasons for an account becoming NPA:

\section{$\underline{\text { External Factors }}$}

\section{Ineffective recovery tribunal:}

The Govt. has set of numbers of recovery tribunals, which works for recovery of loans and advances, due to their carelessness and ineffectiveness in their work 


\section{International Journal of Computing and Business Research (IJCBR)}

ISSN (Online) : 2229-6166

International Manuscript ID : 22296166V7I1201701

Volume 7 Issue 1 May - June 2017

the bank suffers the consequence of non-recovery, their by reducing their profitability and liquidity.

\section{Willful defaults:}

There are borrowers who are competent to pay back loans but are intentionally withdrawing it. These groups of people should be recognized and proper measures should be taken in order to get back the money extended to them as advances and loans.

\section{Natural calamities}

This is the measure factor, which is creating alarming increase in NPAs of the Public and Private sector Banks. Every now and then India is hit by major natural calamities thus making the borrowers unable to pay back there loans.

\section{Industrial sickness:}

Inappropriate project handling, ineffective management, lack of adequate resources, lack of advance technology and day to day changing govt. policies produces industrial sickness. Therefore the banks that finance those industries ultimately end up with a low recovery of their loans reducing their profit and liquidity.

\section{Lack of demand:}

Entrepreneurs in India could not predict their product demand and starts production which ultimately piles up their product thus making them unable to pay back the money they borrow to operate these activities. The banks recover the amount by selling of their assets, which covers a smallest label. Therefore the banks record the non recovered part as NPAs and has to make provision for it.

\section{Change on Govt. policies:}

With every new govt. banking sector gets new policies for its operation, so it has to cope with the changing principles and policies for the regulation of the rising of NPAs.

\section{$\underline{\text { Internal Factors }}$}

\section{Defective lending process:}

There are three cardinal principles of bank lending that have been followed by the commercial banks, that is, Principle of safety, Principle of liquidity and
Principle of profitability. Principle of safety means that the borrower is in a position to pay back the loan, including both principal and interest. The refund of loan depends upon the borrowers, capacity to pay and willingness to pay.

\section{Inappropriate technology:}

Due to improper technology and management information system, market driven decisions on real time basis cannot be taken. Proper MIS and financial accounting system is not implemented in the banks, which leads to poor credit collection and therefore all the branches of the bank should be computerized.

\section{Improper SWOT analysis:}

The inappropriate strength, weakness, opportunity and threat analysis is another reason for increase in NPAs. While providing unsecured advances the banks depend more on the honesty, integrity, financial soundness and credit worthiness of the borrower. so, banks should consider the borrowers own capital investment and bank should collect credit information of the borrowers from:

- Bankers

- Enquiry from market/segment of trade, industry and business.

- From external credit rating agencies.

Banker should examine the balance sheet which shows the true picture of business will be revealed on analysis of profit/loss account and balance sheet. When bankers give loan, he should examine the purpose of the loan. To make sure safety and liquidity, banks should grant loan for productive purpose only. Bank should examine the profitability, viability and long term acceptability of the project while financing.

\section{Poor credit appraisal system:}

Deprived credit appraisal is an additional factor for the increase in NPAs, due to poor credit appraisal the bank gives advances to those who are not able to repay it back. They should use better credit appraisal to reduce the NPAs.

\section{Managerial deficiencies:}

The banker should always select the borrower very cautiously and should take tangible assets as security 


\section{International Journal of Computing and Business Research (IJCBR)}

ISSN (Online) : 2229-6166

International Manuscript ID : 22296166V7I1201701

Volume 7 Issue 1 May - June 2017

to safe guard its interests. When accepting securities, banks should consider the marketability, acceptability, safety and transferability etc. The banker should follow the principle of diversification of risk based on the famous maxim "do not keep all the eggs in one basket", which means that the banker should not grant advances to a few big farms only.

\section{Absence of regular industrial visit:}

The irregularities in spot visit also increases the NPAs, absence of regular visits of bank officials to the customer point decreases the collection of interest and principals on the loan. So, the NPAs can be collected by regular visits.

\section{Impact of NPA:}

1) Profitability: NPA means booking of money in terms of bad asset, which occurred due to wrong choice of client because of the money getting blocked the prodigality of bank decreases not only by the amount of NPA but NPA lead to opportunity cost also as that much of profit invested in some return earning project/asset. So NPA doesn't affect only current profit but also future stream of profit, which may lead to loss of some long-term beneficial opportunity.

2) Liquidity: Money is getting blocked, decreased profit lead to lack of enough cash at hand which lead to borrowing money for shortest period of time which lead to additional cost to the company. Difficulty in operating the functions of bank is another cause of NPA due to lack of money, routine payments and dues.

3) Involvement of Management: Time and efforts of management is another indirect cost which bank has to bear due to NPA. Time and efforts of management in handling and managing NPA would have diverted to some fruitful activities, which would have given good returns. Now a day's banks have special employees to deal and handle NPAs, which is additional cost to the bank.

4) Credit Loss: Bank is facing problem of NPAs then it adversely affect the value of bank in terms of market credit. It will lose its goodwill and brand image and credit which have negative impact to the people who are putting their money in the banks.

Following are some more impact of NPA:

- NPAs causes to decrease the value of share sometimes even below their book value in the capital market.

- $\quad$ NPAs affect the risk facing ability of banks.

- NPAs reduce the earning capacity of assets and badly affect the ROI.

- The cost of capital will go up.

- The assets and liability mismatch will widen.

- The economic value additions (EVA) by banks get upset because EVA is equal to the net operating profit minus cost of capital.

\section{Measures to Control NPAs}

In present scenario, NPAs are at the core of financial problem of the banks. Concrete efforts have to be made to improve recovery performance. Measures required to be undertaken are mainly two fold. Banks should make efforts first to avoid fresh addition on NPAs by their effective presentation appraisal and secondly to recover the amount from accounts which have already turned bad.

(1) Preventive Measures: Most of the bankers feel that genuine viability problem of the borrowing units, weakness in credit appraisal system, absence of effective monitoring and supervision of loan account, absence of credit information sharing among the banks etc. are some of the significant causative factors of high level of NPAs internal to the banks.

- For prevention of the fresh inflow of funds into the non-performing category, banks should reformulate their credit appraisal techniques.

- Proper evaluation of the loan application may help in detecting the unviable projects at the first instance.

- Full information about unit, industry, its financial stake, management etc. should be collected.

- Industrial cell should be established at the bank level, which would have complete 


\section{International Journal of Computing and Business Research (IJCBR)}

ISSN (Online) : 2229-6166

International Manuscript ID : 22296166V7I1201701

Volume 7 Issue 1 May - June 2017

information about the industry and its prospects in future.

- Proper credit monitoring should be equally emphasized. There should be proper flow of information from the units regarding their financial area, annual accounts, stock reports etc., which would enable the banker to know the need based credit requirement of borrower and warning signals for taking quick remedial action.

- Banks should inspect the progress of the project or the business. Separate monitoring department should be established in large branches for periodical review of accounts, comparative risk analysis and compliance of terms and conditions of sanction. Equal emphasis should be given for monitoring of standard assets also.

- Banks should be equipped with latest credit risk management techniques to protect the bank funds and minimize insolvency risks. Banks should develop credit derivatives markets to avoid these risks. There should be regular visits of senior bank officers from all public sector banks for specialized training in training institutes to equip them with latest procedures and practices.

(2) Curative Measures: Besides making efforts to stop the fresh additions of NPAs banks have to take steps to recover the amount from assets, which have already slipped into NPAs category. Significant causative factors highlighted were slow recovery of legal cases, willful default induced by officially announced loan waiver schemes etc. The Indian legal system is sympathetic towards the borrowers and works against the banks interest.

- Despite most of their loans being backed by security, banks are unable to enforce their claims on the collateral, when the loans turn non-performing and therefore loan recoveries have been insignificant.

- The Narshimham Committee on financial system (1991) has recommended the establishment of Debt Recovery Tribunals (DRT) for the speedy recovery of the assets from NPAs category. On the basis of recommendations 22 DRTs were established by passing the bill on Recovery of Debt due to Banks and Financial Institutions Act 1993. But the performance of DRTs for the past years has not been found satisfactory or up to the mark.

- The Act has some limitations, which must be removed to make its effective implementation.

- At present, One presiding officer is handling at least $80-90$ cases per day. It is suggested that DRT Act may be amended to enable the central government to appoint additional presiding officers for speedy disposal of recovery cases.

- One of the major factors accounting for delay in disposing of application by DRT caused due to refusal by defendants to accept the summons and at times due to change in address too.

- DRT may be empowered to order service of summons by hand, registered post and by publications simultaneously. Attachment of immovable property of borrower is not admitted due to service of summons.

- Enforcement of security and obtaining court decree take unduly long time, it encourages willful default and ultimately the banks may be compelled to write off loans. Willful default should be declared a criminal offence.

- Government should not go for mass waiver of interest/ installments as it sends unhealthy signals to the borrower. During 1990-91 there was a massive waiver of rural debt amounting to over Rs. 15000 crore and Rs. 65000 crore in 2008. These types of activities put a premium on willful default and dishonesty. It lowers the repayment ethics.

- In case of government sponsored schemes government should assist in recovery. It may be noted that suggestions enumerated will go a long way in reducing the NPAs. This will only considerably improve the profitability of the banks, improve the quality of assets, but also make the Indian 


\section{International Journal of Computing and Business Research (IJCBR)}

ISSN (Online) : 2229-6166

International Manuscript ID : 22296166V7I1201701

Volume 7 Issue 1 May - June 2017

"Banking system stringent, resilient and geared to meet the challenges of globalization.

\section{Conclusion:}

NPAs reflect the overall performance of the banks. The NPAs have always been a big worry for the banks in India. The Indian banking sector faced a serious problem of NPAs. A high level of NPAs suggests high probability of a large number of credit defaults that affect the profitability and liquidity of banks. The extent of NPAs has comparatively higher in public sectors banks. To improve the efficiency and profitability, the NPAs have to be scheduled. Various steps have been taken by government to reduce the NPAs. The problem of recovery is not only with small borrowers but with large borrowers and a strict policy should be followed for solving this problem. The government should also make more provisions for faster settlement of pending cases. It is highly impossible to have zero percentage of NPAs. But at least Indian banks should take care to ensure that they give loans to creditworthy customers.

\section{References:}

- $\quad$ Rajendra Kakker. "NPA Management - Role of Asset Reconstruction Companies" - IBA

- Bulletin-Volume 4-p.no: 11- 14, 2004

- B.Selvarajan \& G. Vadivalagan, "A Study on Management of Non Performing Assets in Priority Sector reference to Indian Bank and
Public Sector Banks", Global Journal of Management and Business Research, Vol.13, Issue 1 Version 1.0.

- Kanika Goyal, "Empirical Study of NonPerforming Assets Management of Indian Public

- Sector Banks", APJRBM Volume 1, Issue 1, October 2010.C.S. Balasubramaniam, "Non Performing Assets and Profitability of Commercial Banks in India: Assessment and Emerging Issues", Journal of Research in Commerce \& Management, Vol. 1, Issue 7, pp. 41-57.

- G.Rangarajan, address, financial Sector Reforms : The Indian Experience at bankers =Training centre , Kathmandu, Reserve Bank of India Bulletin, Vol. LI, No.7:549-59.

- G.V. Bhavani Prasad \& D. Veena, "NPAs Reduction Strategies for Commercial Banks in India", International Journal of Management and Business Studies, Vol.1 Issue3, September, pp.47-53.

- Kamini Rai, "Study on Performance of NPAs of Indian Commercial Banks" Asian Journal of Research Banking and Finance, Volume 2, Issue 12,December.

Rai, K., "Study on performance of NPAs of

- Indian commercial banks", Asian Journal of Research in Banking and finance, Vol. 2, Issue $12,2012$. 